\title{
EDITORIAL
}

\section{On Trade-Offs and Excellence: An Overview of Basic Issues}

\section{INTRODUCTION}

There is scarcely an issue more central to higher education than its financing, for depending on how the financial frame is modified, so whole areas of institutional activity are themselves faced with often quite massive turbulence. The numbers of students each lecturer is expected to deal with, the number of hours he or she is expected to teach and from there, what time is left for research after administration has taken its toll, all undergo startling revision. Nor does the 'knock-on' effect stop here. Diversification of resources and the seeking for other sources of funds are explicit in most of the changes that have taken place in this domain. More time and energy and certainly more ingenuity are required to locate them and to tap them. This time is rarely, though clearly it ought to be, taken into account in both time-budgeting of departments and of central administration.

The search for alternative sources of funding, if difficult even in the most prosperous of economies, becomes a task of almost superhuman dimensions when the country's economy is itself not in the best of health. Yet this is precisely the situation that is faced daily by universities in the developing world. There are, of course, a number of solutions to hand, but not all of them are applicable in exactly the same way as they have been, for instance, in the Northern economies. Research selectivity is precisely one such area.

A number of Western European countries - Britain being one, the Netherlands another - now propose to limit research to certain wellestablished centres of excellence. This, of course, presupposes that such limitation will not damage the country's research base. It is a large presupposition. The situation is quite different for those countries where the research base is itself developing or, alternatively, held back by notorious lack of finance. In such circumstances, research selectivity, cutting further into the substance of an of ten fragile research economy is hardly wise, let alone sensible.

Given the crucial strategic importance that financing has for the development of all systems of higher education, the International Association of Universities, in conjunction with the African Association of Universities, took the initiative to open up this discussion for those who, whether teachers, researchers or administrators, face as their daily fare the consequences of resource shortage in its most dramatic form. The discussion, hosted by the University of Ghana, brought together some 70 participants and took place on 28 and 29 November 1991 .

Our exploration of the issues posed by the title of the colloquium, 'Towards a Long-term Strategy for Financing Higher Education and Research in Developing Countries', began on a sombre note. We were reminded that resources are shrinking, but never has society's expectation of what the university may deliver been higher. Our first speaker echoed these observations; in his opening statement he alluded to deteriorating terms of trade, and to a feeling of deep apprehension pervading those who, today, look at the state of higher education in Africa.

Though human resources are, clearly, the most precious of a nation's assets, it is no less clear that demand for higher education has outstripped the ability of many nations to pay for it from public funds. We were given some dramatic figures to illustrate this. And, throughout our discussion, we received from all our speakers no less dramatic examples of what this means in terms of declining conditions of study and conditions of work for students and staff as much as for researchers.

\section{THE END OF PANACEAS}

However, common conditions do not, as was previously believed, of necessity lead to common solutions. Higher education, as Jamil Salmi's paper stated without peradventure, is highly complex and shaped by the very particular conditions - economic, historical, social and political that combine in very different ways from one country to another. In short, if we are to talk about long-term strategies (and, by definition, most strategies are, by contrast to tactics, long-term), those strategies have to be shaped to the specificities of the individual nation, even though they might tend towards a common goal.

Our first speaker reminded us that despite the vanishing of global solutions, most higher education systems still seek to adhere to four generic principles: the adherence to quality, the upkeep of institutional responsiveness to change, the drive towards greater efficiency and the covenant of equity.

\section{A RANGE OF TRADE-OFFS}

It is within the framework set by these four generic principles that the issue of financing strategies is located. But in a time of constraint, any strategy has to involve the calculation of trade-offs. If one is to meet a continued high demand for higher education and, at the same time, to hew resolutely quality and excellence, costs must be reduced. One solution which our first speaker analysed was that of 'systemic segmentation'; that is, the restructuring and creation of a non-university sector to accommodate further social demand.

Another trade-off involves changing the basis on which budgetary formulas are drawn up. The linking of institutional performance to budgetary allocation is now becoming widely practised, either by input budgeting or by output budgeting. Now this approach is part of a rather broader shift that we see elsewhere in higher education, and involves a major shift in evaluating the performance of higher education systems away from inputs and away from student numbers and enrolment ratios as an indicator of institutional or systems efficiency. To some, this may seem to be a departure from a fundamental criterion of access to higher education and thus of equality. What we see here and there-and the Netherlands was cited as an example - is the move toward assessing higher education and, by extension, its budget, on the basis of an institution's output; that is, in terms of those graduating within the specified minimum time as a percentage of all those who entered X years previously. This, of course, poses the question of how far efficiency, once defined in terms of access and equity, is operationally compatible with efficiency defined in terms of output and utilitarian values, ie appropriate skills, speed of entry into the labour market etc. But this, again, is an example of some of the trade-offs that our first speaker was involved in exposing.

\section{DIVERSIFICATION OF FUNDING SOURCES AND AUTONOMY}

Diversification of funding sources was another issue which, first broached by Jamil Salmi, was pursued by many of our subsequent speakers, whether in the context of research funding and science policy as argued by Cisse or, later, in terms of innovation management as developed by 
Essien or the funding of graduate students by Mshigeni. Here the trade-off is of a rather different order, but no less radical for all that. For if public monies can no longer sustain the myriad demands that the nation places on higher education, higher education must perforce 'go forth into the highways and byways that ... its coffers may be full.' But if it is to do this successfully, it must have that administrative and legal flexibility that allows it to do so. And it is here that the most eloquent argument, although certainly utilitarian and pragmatic, can be made on behalf of reinforcing institutional autonomy.

Control over the utilization of resources, the reward of enterprise and initative - in short, the degree of responsiveness to outside change is, it is believed, made considerably easier if such autonomy is granted. But there is a condition: if institutions are to have such autonomy, they must also have the capacity to evaluate their own performance, their strengths, their potentials not only to 'speak truth to power' (to parody the well-known title of the book by Aaron Wildavski) and they must also be able to talk turkey to private sector bodies, parastatals and donor agencies.

There is, I think, no need for me to point out the clearly delicate political implications that some might see as accompanying such a move. But even for governments, deeply enmeshed in the labyrinth of options and possibilities, there are trade-offs to be made as well.

\section{PRIOR QUESTIONS FOR STRATEGIC PLANNERS}

One may detect a similar questioning, though perhaps more subtly advanced, in the broad-ranging exposé of Abdel-Motaal. Here we entered into the realm of those types of framework decision which planners faced prior to setting priorities. What are likely to be the subjects most in demand in the future? Should research be given a more applied slant? Should higher education move towards cost-sharing with students? In his examination of strategic perspectives on the planning of higher education, Abdel-Motaal gave us some pragmatic illustrations of the way change is beginning to impact on Egyptian higher education. At the risk of doing violence to a most complex presentation, I would be inclined to see his argumentation as throwing up one of the basic issues that the crisis places on us: namely, the introduction of a policy of differential treatment and the move towards targeted grants for students in keeping with family income. The introduction of fees - even if only nominal is, of course, a step towards cost-sharing. However, this too is a delicate matter and, as we were reminded, such measures, though necessary, require a high degree of public consensus and a widespread consultation prior to the development of a policy which, to certain interests and not least students and their parents, may often appear to be highly radical even if, from a financial standpoint and from the perspective of government, such individual amounts are minimal in the contribution they bring in.

Yet here, too, our speaker endorsed the views of his predecessor in calling on governments to operate a certain self-denying ordinance. He called for minimal government intervention and a depoliticization of the university's affairs.

\section{SEGMENTATION, PRIVATIZATION AND MIXED FUNDING MODES}

Though Egypt is turning towards a policy of segmentation by creating a sector outside the university, segmentation and privatization are not always solutions that work towards upholding the principle of equity. Indeed, the Brazilian example as presented by Martins Romêo, seems to have resulted in certain effets pervers. Private universities, which take the greater majority of the nation's students, are fee paying, though the students they take are neither the social nor the intellectual élite. By a curious paradox it is the public, non-fee-paying, sector which enjoys both dimensions of élitism. In short, the poor pay for what the rich get for free. And though one cannot deny that this is one way of dealing with demand in excess of what the State can accommodate, one doubts that such a solution would prove either acceptable or even easily transplantable into the African setting.

Other speakers during our discussion raised the issue of differentiation in another form - this time related to the funding of courses. One suggestion was that public funds should support only those courses deemed 'in the national interest'. Those not so designated, would be financed by the individual student - or more likely by his relatives! Apart from the long-term effects such a policy might have on channelling student demand, it does raise interesting issues as to whether mixed financing modes for study programmes - from government, parastatals and private sources - might not be a promising approach: a compromise between the two extremes of wholly government funding on the one side and total cost-sharing with students on the other. Either way, I am afraid, what this illustrates is once again the old adage, well known to public policy analysts, that 'There ain't no free lunch.'

\section{RESEARCH AS OUTPUT EVALUATION}

Earlier, I mentioned the concept of the shift in certain countries towards the question of evaluating an institution on the basis of its output, and one of the outputs I suggested was qualified students. But the university is not a single-product enterprise - students are only one vehicle by which knowledge is transferred into the community and, it is hoped, into the occupational structure. There are other forms, and virtually all of us would agree that research is no less a central activity. Indeed, it is research that distinguishes a university from a training institute. Research is a vital output of the university system and indeed it is upon this that, will ye or nil ye, institutional standing, repute, prestige and excellence are founded. 1

The theme of the fragility of research policy and research financing was laid before us by Cisse. Vital though this activity is to the transformation towards a technology-based and knowledge-based economy, it is clear nevertheless that the gap between industrialized and developing countries is widening in the research domain. His analysis showed that if inadequate investment was certainly one explanation, it was not the only one: no less important were marked deficiencies in the management of research and in its organization. His portrayal of the research system in Africa was one of a plethora of different structures, juridical and statutory, and the conflicts of oversight exercized through different administrative and ministerial agencies. Dynamism was certainly there, but it was there in units often too small to be viable, unable to reach a critical mass and bedevilled by lack of a coherent framework. Little interdisciplinary research is undertaken and, furthermore, research consortia bringing together a number of different centres to collaborate in the same area was equally apparent. This, the speaker argued, ought to be encouraged further.

\section{STRUCTURAL PROBLEMS IN RESEARCH POLICY}

The impression one retains is that though one result of massive undergraduate enrolments is often to divert attention away from research and to concentrate instead on teaching, the problem lies less in the universities themselves than with the basic elements of national science policy - or its absence. A further dimension - though one suspects that perhaps this has greater acuity in those systems which, following the French 
model, have a research organization running in parallel to the university ${ }^{2}-$ is the dual basis of research, in part located in university and in part in $R \& D$ institutes.

It is here, one suspects, that if finance is a goodly part of the problem, there are other aspects which are no less deleterious; territory disputes between different Ministries and lack of central coordination. These are not conjunctural problems, though certainly an unhappy conjuncture will aggravate them. They are structural problems and are related only in a secondary manner to unadapted systems of financial allocation.

But incoherence in the national management of research naturally (one is almost tempted to say, inevitably) compounds the difficulties when the number of partner institutions with a research interest multiplies. But here again, we come back to the basic question of institutional development and equally to institutional evaluation. If research is to be part of the normal channel by which the university advances knowledge, then research requires a higher degree of rationality in its organization. The questions here are, of course: Where does one begin to put management structures to handle research in place? At the national level? At the institutional level? And in what order? This is indeed a ticklish matter. Should one seek first to extend research management at the national level with the risk of reinforcing a degree of centralized control that many feel is misplaced, given the need for institutional flexibility referred to by earlier speakers, or should one start off at the base unit level? As one of our commentators pointed out, one may perhaps seek to optimalize research development by concentrating on installing systematic management at the establishment level.

What one can say, with all the caution of the legal saw, is that 'circumstances will alter cases'. Such a view is fully in keeping with an earlier remark by Jamil Salmi that blockbuster solutions are best avoided. Instead, one should seek solutions adapted to the circumstances in which the country finds itself.

\section{THE TRANSFER OF KNOWLEDGE}

Research, as I have pointed out, is largely a process of the university creating new knowledge and transferring it, sometimes to the community and at other times to the wider community of the Republic of Letters and the Kingdom of Science. But the whole issue of the transfer of knowledge is a matter of the utmost complexity, as Essien's contribution reminded us. His case study on the management of innovation, though at one level continuing the issue of management, at another level raises some deeply disquieting aspects. In his tracing of the innovation process from the identification of a problem to its eventual transfer into the 'external' world of producers, financiers and firms, he explicitly poses the question: 'Where should one place limits to the university's responsibilities?' To be sure, he provided us with a clear and lucid answer - namely at the point where development funds for production are required.

\section{GREAT EXPECTATIONS}

But the same question, when placed against the expectations that the nation has of its universities, poses no less important issues. Higher education has undergone immense 'responsibility enlargement' 3 just as it has undergone equally immense financial reduction. As more tasks are thrust on it in such circumstances, the fewer tasks it can succeed in. Should we not consider exploring - naturally, at a later date - what the limits of the universities' responsibility really are?

In essence, Essien's sketch of the various structures that may be put in place to stimulate the innovative capacity of our universities stands clearly as the reverse process of the university reaching out to the community. Rather, the processes he laid before us are the business community reaching into the university. Patent Units, Production Units, Consultancy Units are, in short, permanent structures to catalyse the university and to enable it to render service to the external community. They are also, in a curious manner, the means of maintaining creativity and thus, to revert to our four generic principles, a way of upholding quality among academic staff. What one might question are the consequences this policy might have for the introduction of differential conditions of service. One of these consequences might be for academic staff, by dint of their being split off - some being assigned into Production Units, others to permanent Consultancy Services etc - to enjoy different terms of employment. Here, and I express a personal opinion, it is unlikely that by simply isolating those Units away from the university, one will be able to avoid conflict as a result of introducing differential salary scales. But clearly this, to parody Victor Hugo, is an idea whose time is come. Its potential for diversifying income streams is of critical importance, though it is only fair to point out that, in this case, diversity of income is a trade-off against possible staff unrest and certainly disquiet.

\section{PRESERVING THE INTELLECTUAL SEED CORN}

Academic staff ought to be the cutting edge of creativity. Still, the seed corn, to change the metaphor for a moment, is, as Mshigeni brought home to us with great eloquence, the graduate research students. From them future researchers are made and out of them will, it is hoped, spring the future industrial and technological innovators. In contrast to Essien, Mshigeni was concerned with the university putting in place those structures that will enable it to reach out to the community. His presentation was (though I suspect he would deny this) an excellent case study of the importance of the charismatic leader. We were given a dramatic account of the way in which budget cuts affect the basic conditions necessary for the building up of a critical mass within the highly qualified output which the university puts forth.

Equally clearly, this contribution demonstrated with a limpidity that one can only admire, the importance of consortia and cooperation. The benefits to be had from South-South links as well as South-North links were forcefully set out. And, like his colleague from Nigeria, he called for the development of a consultancy capacity to be part of Africa's universities.

Mshigeni reminded us - and in so doing he rejoined a theme touched on by Jamil Salmi - that despite all the burdens under which the universities labour, their first task is to produce excellence - among first degree students, graduates and also academic staff.

\section{A FINAL ADMONITION}

In the true manner of the biblical sage, Mshigeni took us gently to task in the form of ten commandments. Of these ten commandments, the one I retain as one that should come as a trumpet blast in the midst of our difficult times is: 'Thou shalt not despair'.

Nor shall we forget that salvation, as much personal as institutional, springs from one's own efforts. Seek and Ye shall find. Labour and do not count the cost. These are the messages received throughout the Conference. They have been variously couched. In the language of the economist, such injunctures appear as: 'Diversify the sources of thy income'; in the parlance of the management expert we are bidden to: 'Set forth thy structures so they shall bring new and wondrous things into thy universities.' In truth, to do this, we shall have to meander through 
the bureaucracy. That was ever our lot. We shall also remember that knowledge is power, for that truth has been our daily conviction since we were all first-year students. Above all, we must not despair, either of our own adaptability or of our own ingenuity.

Guy Neave

\section{NOTES}

1. Clark, Burton R. (1983) Higher Education System: Academic Organization in Cross-national Perspective, Berkeley, Los Angeles, London, University of California Press.

2. Neave, Guy (in press) France, In Burton R. Clark (ed) The Research Foundation of Graduate Study, Los Angeles, University of California Graduate School of Education.

3. For the concept of 'responsibility enlargement', see Guy Neave (1991) The Teaching Nation: Prospects for Teachers in the European Community, Oxford, Pergamon Books, (especially Chapters 1 and 5). Also Neave, Guy (1991) Transformations et défis: la mobilisation des enseignants européens, Document de Base pour la Conférence 'La Profession de l'Enseignant en Europe', 3-5 October 1991, Noordwijkerhout, Netherlands (especially paragraphs 5.7.1 to 12.4.1). 